\title{
Sites of violence and their communities: critical memory studies in the post-human era
}

\author{
Roma Sendyka ${ }^{1}$ \\ 1 Jagiellonian University, Kraków, Poland \\ Corresponding author: Roma Sendyka (roma.sendyka@uj.edu.pl)
}

Published 23 November 2021

\begin{abstract}
"Sites of Violence and their Communities" presents the results of a research project that brought together scholars and practitioners of memory work in an attempt to critically reinterpret the links between sites, their (human, and non-human) users, and memory. These interdisciplinary discussions focused on overlooked, repressed or ignored sites of violence that may benefit from new approaches to memory studies, approaches that go beyond the traditional focus on communication, symbolism, representation and communality. Clandestine or contested sites, in particular, pose challenging questions about memory practices and policies: about the status of unacknowledged victims and those who witnessed their deaths; about those who have inherited the position of "bystander"; about the ontology of human remains; and about the ontologies of the sites themselves, with the natural and communal environments implicated in their perdurance. Claude Lanzmann - one of the first to undertake rigorous research on abandoned, uncommemorated or clandestine sites of violence - responded to Pierre Nora's seminal conception with his work and with the critical notion of "non-lieux de mémoire." Methodologies emerging from more traditional as well as recently introduced perspectives (like forensic, ecological, and material ones) allowed team members to engage with such "non-sites of memory" from new angles. The goal was to consider the needs and interests of post-conflict societies; to identify and critically read unofficial transmissions of memory; and to re-locate memory in new contexts - in the grassroots of social, political and institutional processes where the human, post-human and natural merge with unanticipated mnemonic dynamics.
\end{abstract}

\section{Key Words}

Eastern Europe, forensic turn, Holocaust, lieux de mémoire, memory cultures, non-sites of memory, post-violence societies, sites of memory

\section{Introduction}

Central and Eastern Europe, the scene of brutal genocides in the past century, is dotted with sites of trauma. The IHRA Killing Sites initiative has documented that 2.2 million Jews were killed by bullets at dispersed killing sites - either in the Einsatzgruppen post-1941 executions or in the "third phase of the Holocaust" when occupants cooperated with locals finding and killing those trying to hide on the Aryan side (International Holocaust Remembrance Alliance 2015; Engelking and Grabowski 2018). In Bloodlands: Europe between Hitler and Stalin Timothy Snyder (2010) expands that number, adding other mass killings perpetrated by different totalitarian agents.
Today, only some of those potential sites of memory are marked with plaques, gravestones or memorials. What is the meaning or impact of sites that have been left behind, contested or forgotten and that still contain the victims' bodies? The research presented in the following article was focused on the question of the societal and cultural impact generated by sites that have been excluded from social imaginaries. The initial hypothesis was that some "sites of history" that have not been transformed into "sites of memory" (Nora 1984-1992) nevertheless persist in a peculiar, negative way in the practices of the local community. Hence, sites expelled from the public discourse and ethical responses can still generate a significant impact on nearby communities. Since the problematic sites are kept 
outside the social imaginary, the responses to them - one may suppose - are not part of the easily-readable symbolic system of the official culture. An alternative approach is therefore needed, a more sensitive tool required, to spot and assess possible interactions.

The key intention of the collaborative research in the project "Uncommemorated Genocide Sites and Their Impact on Collective Memory, Cultural Identity, Ethical Attitudes and Intercultural Relations in Contemporary Poland" (2016-2020) was to draw into conversation researchers, artists and professionals in order to construct an operative tool for memory studies - one that would make it possible to include more efficiently into shared awareness and research programs such post-violence sites that are today clandestine, contested, repressed, ousted from public discussions, omitted in symbolization processes, and overlooked in the management of collective and cultural memory. The texts presented in this issue give an account of this interdisciplinary dialogue.

\section{From site to non-site of memory}

'Pits', 'holes', 'mounds', 'molehills', 'knolls', 'hollows', 'carcass dumps' - these are the English equivalents of names mentioned by the interviewees during our research. Trying to identify the places where human remains were deposited after the war, the witnesses symptomatically omitted the word 'grave'. This denotational effort reveals that in the case of clandestine post-violence sites we often deal with nameless objects. It also demonstrates the instability and un-rootedness (in discourse and in experience) of the uncommemorated post-terror sites that the research team was looking for.

This locally demonstrated terminological helplessness has an equivalent in the professional discursive circulation. Seeking a term for our research object, we traced the movement of theory around sites generating negative interactions: since the 1990s, there have emerged many concepts which could potentially aid our act of naming. It is worth recalling "sites in spite of all" (Didi-Huberman 1998), "bad places" (Hayden 1997), "Nicht-Ort" and "Un-Ort" [nonsites] (Saryusz-Wolska 2011), "voids" (Huyssen 1997; Liebeskind 2003) or "Geisterorte" [phantom-sites] (Assmann 1999). In the past decade, research on post-violence sites supplemented this vocabulary with notions related to the category of landscape: "campscapes" (van der Laarse, Rapson 2015), "traumascapes" (Tumarkin 2015; see also: "trauma sites" in: Violi 2012), "terrorscapes" (Laarse et al. 2014; see also: "terrorspaces" in: Otto 2009), "forensic landscapes", and, more broadly, "Holocaust landscapes" (Cole et al. 2014; Cole 2016; Małczyński 2018) and "landscapes of postmemory" (Kaplan 2010; Szczepan 2014).

However, a particularly useful (and also the earliest) term referring to abandoned post-violence sites in Poland was proposed outside academia - by Claude Lanzmann, the French documentary filmmaker who in the 1970s visited with his crew uncommemorated post-camp and post-ghetto sites. His concept of "non-sites of memory" (non-lieux de mémoire; Lanzmann 1986, 1990, 2007) became the basic term in our research. Lanzmann's idea naturally meant turning the edge of criticism against the very core of the category of "site of memory", proposed by the French historian Pierre Nora and gaining immense popularity in the 1980s (LaCapra 1997). Consequently, choosing to apply Lanzmann's concept in our research, we faced a new task. As Astrid Erll observed, "Pierre Nora's lieux de mémoire have proven to be the most influential notion internationally" in the "context of what may be called "new cultural memory studies"" (Erll 2011a: 13); it was foundational for the second phase of memory studies, reborn in the 1980s and accompanying the phenomenon described as the "memory boom" (Erll 2011b: 4). In our empirical search for non-sites of memory in provincial Poland, at the same time, though at a different, theoretical level, we also engaged in a critical reinterpretation of the tradition of memory studies, joining the critics of one of its key concepts (François and Schulze 2001; Tai 2001; Anderson 2004; Schmidt 2004; Rothberg 2010).

While Lanzmann's criticism does not broaden the list of accusations, it emphasizes the presence of objects which can be considered the obverse of what Nora wanted to describe. This inscribes his activity, in the spirit of the time, into the cognitive practices of deconstruction, in which a given category can be revised through revealing that which had to be omitted or muted in order for it to crystallize. In our project, we continued Lanzmann's approach, trying to transform the cultural critic's intuitive expression into an instrument of academic thinking in the area of memory studies. The French director's critical proposition stemmed from years of extensive field research, interviews with surviving witnesses, and a search for locations akin to those that were our focus - in other words, it was built on an empirical foundation, one that is no longer available today. It is therefore worthwhile to revisit the data obtained in the 1970s and the phenomena manifest in them, approaching them as a hypothesis that needs verification. What is at stake is perhaps a deeper understanding of the local practices of memory, ungraspable by the interpretative practices developed in Western culture (Głowacka 2016).

We understand non-sites of memory as dispersed locations of various genocides, ethnic cleansings, and other similarly motivated acts of violence.

The basic indicator is a lack of information (altogether or of proper, founded information), of material forms of commemoration (plaques, monuments, museums), and of reparations (any official designation of the scope of the territory in question). Non-sites of memory also have in common the past or continued presence of human remains (bodies of deceased persons) that have not been neutralized by funerary rites. These sites do not, meanwhile, share physical characteristics: they may be extensive or minute, urban or rural, though they are often characterized by

1 See: Campscapes: https://www.campscapes.org/ (access 10.09.2020). 


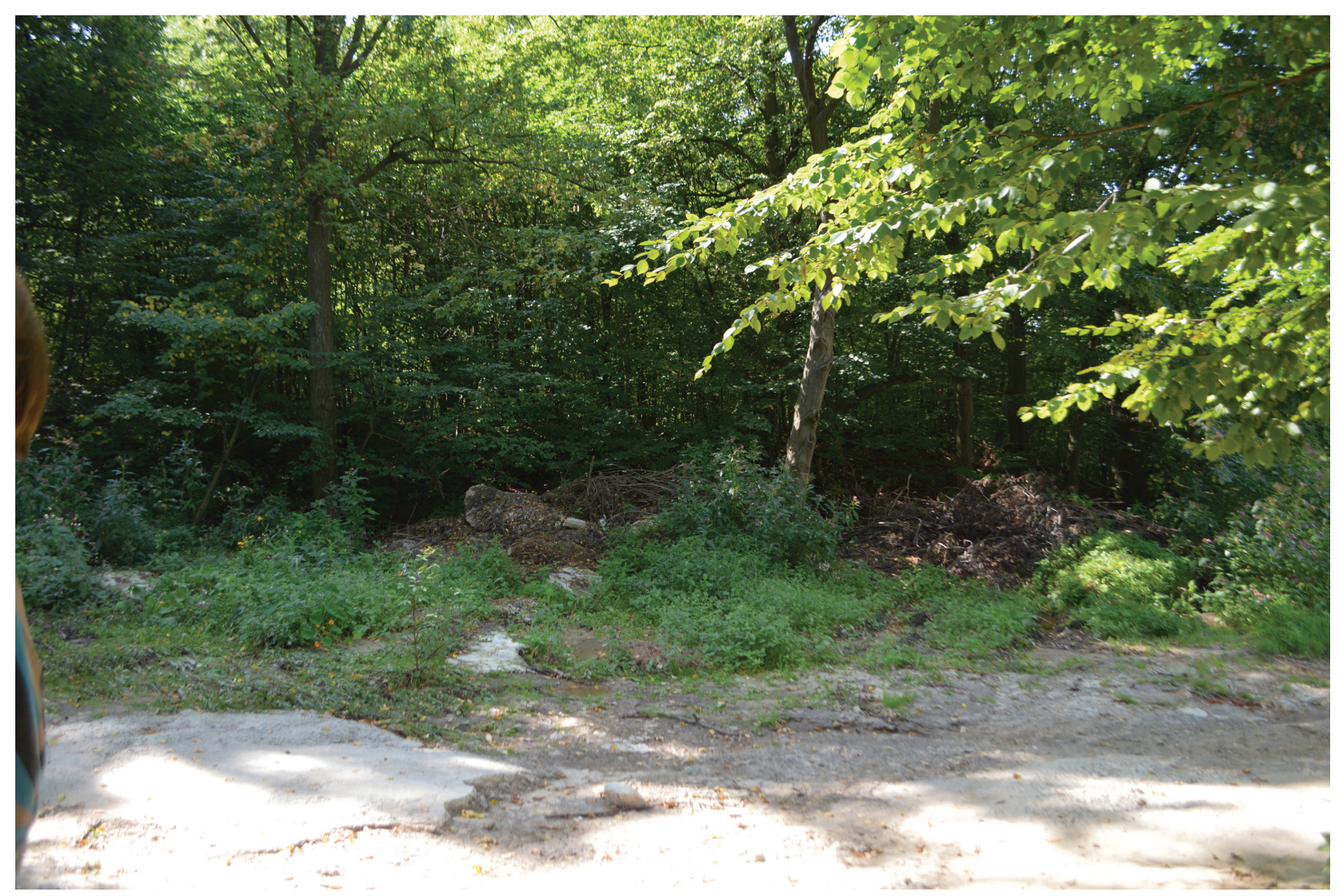

Figure 1. Uncommemorated site in Radecznica, in eastern Poland. Phot. Roma Sendyka.

some variety of physical blending of the organic order (human remains, plants, animals) and to the inorganic order (ruins, new construction). The victims who should be commemorated on such sites typically have a collective identity (usually ethnic) distinct from the society currently living in the area, whose self-conception is threatened by the occurrence of the non-site of memory. Such localities are transformed, manipulated, neglected, or contested in some other way (often devastated or littered), the resultant forsaking of memorialization leading to ethnically problematic revitalization that draws criticism (Sendyka 2016a: 700).

In order to fully understand the specifics of these sites, it is necessary to employ theories distinguishing between "space" and "place" (Tuan), the categories of "belonging to home" and the "un-canny" (heimlich-unheimlichFreud), "dwelling" (Ingold) and "placelessness" (Relph, Heidegger, Augé, Foucault), as well as venturing outside the anthropocentric paradigm.

The objects to which we devote this study are sites that witnessed war-time violence, "sites of history" that have not, however, been endowed with the status of symbolic objects anchoring the communal relation to the past. ${ }^{2} \mathrm{On}$ the contrary: the community actively keeps these places from coming out of the mnemonic shadow (Eisenhuth and Sabrow 2017). Thus, non-sites of memory are as constitutive for group identity as 'open' sites of memory. In this regard, our argument is that we do not deal here with amnesia or forgetting, with a permanent and ultimate removal of a particular object, but rather with another kind of negative work of memory: "non-memory" (Hirszowicz and Neyman 2001, 2007; Kwiatkowski 2009; Nowak et al. 2018), which is transferred unofficially, in personal, close circulation, through deformed symbolic means (myths, legends, maxims, broken sentences, linguistic slips), and especially though non-symbolic ones (gestures, facial expressions, voice prosody and timbre, body language, special interactions with things and people, routes around particular surroundings, practices of using a given area) (Sendyka 2016b).

\section{Methods: micromemory studies, close- range theory and theoretical objects}

Topographical objects that seem to be unspecific and semantically unclear have been revealed in programs such as Yad Vashem's "Untold Stories", which collected testimonies on mass executions in the Eastern Front after 1941, "La Shoah par balles" by the French organization

2 Nora's premise not only concerned real but also imagined or created objects which secure the communality of the acts of relating to the past. In our project, the focus has been on sites in the literal sense of the word: topographically defined localities. While symbolic objects of another order do appear in our research, they are approached as auxiliary, secondary to the principal topographical field objects. 
Yahad-In Unum, which since 2010 has archived statements from witnesses of the actions of Einsatzgruppen, German killing squads, in Eastern Europe, or in initiatives aimed at identifying sites of Judenjagd (the hunt for the Jews from the "third phase of the Holocaust"), by foundations (e.g. The Matzevah Foundation, Fundacja Zapomniane/Forgotten Foundation), religious organizations (The Rabbinical Commission for Jewish Cemeteries in Poland), state institutions as well as thanks to the efforts of many private individuals. ${ }^{3}$ The fact that these localities remain uncommemorated causes a cognitive dissonance in those who have adopted the standards of European memory culture (based on the "facing the past" framework and "duty to remember" politics of commemoration - see David 2017). This, in turn, opens the way to morally motivated criticism of the actions of local communities, seen as repressing or downplaying the significance of the Shoah. Countering this simplifying approach, research on the "banality of forgetting" by Jacek Nowak, Sławomir Kapralski and Dariusz Niedźwiedzki (2018) has shown a highly complicated knot of memory, which emerged after Eastern European countries regained their independence as a combination of factors such as the memory of World War II, post-war anomie and communist repressions, un(der)recognized significance of the Shoah, official identity discourses of the communist times, the trauma of the 1989 transformation, resistance against what is perceived as the new 'European' colonization, and the rebirth of nationalistic identity. Thus understood, the mnemonic reality of the region appears as an intricate noeud de mémoire, which calls for more complex research tools - tools that, as Michael Rothberg once suggested, would enable studying remembrance without resorting to a priori limiting presumptions. Instead, they should rhizomatically capture the complexity of the structure under research, exceeding "attempts at territorialization [whether at the local or national level] and identitarian reduction" (Rothberg 2010: 7).

The research team of the "Uncommemorated Genocide Sites" project centered their exploration of the practices of remembering on sites characterized by the greatest dissonance between the cultural and religious imperative of
European culture, which demands commemoration of the fallen and the killed, and the fact that this rule is practically suspended in certain situations, and with regard to certain bodies. Our aim was to understand how "living with all the dead under our meadows and fields" (Pollack 2014: 91) became possible in Eastern Europe. Thus, we inquired about the processes of selecting sites worthy or unworthy of commemoration; we observed the 'life' of uncommemorated sites, we described social and cultural phenomena generated by 'contested' locations of violence, and, in the broadest sense possible, we made an attempt at cataloguing the functions of these places in local and supra-local memory cultures. Moreover, during our fieldwork and analytical research, we watched the gradual transformation of uncommemorated sites into sites of memory, inquiring about the necessary preconditions for the change of their memorial status.

Selecting our cases, we drew on guidelines from organizations engaged in field work aimed at identifying uncommemorated body disposal pits. We wanted our objects to constitute a diverse array of sites, related to the deaths of people from different social and ethnic groups. Out of the locations we learnt about, we focused on those which we considered paradigmatic, in sufficient numbers to create an exhaustive typology. Radecznica in the Roztocze region of eastern Poland drew our interest due to the findings of The Rabbinical Commission for Jewish Cemeteries in Poland (RCC), which examined dispersed pits containing the bodies of the victims of the Shoah. At the same time, we observed the process of discovering the bodies of other victims and of establishing a different arrangement of symbols: a mausoleum is currently being created in this village to house the bodies of the "cursed soldiers", members of the anti-communist underground, which have also been found in the region; the history of these soldiers is promoted by Polish right-wing authorities. ${ }^{4}$ Bielcza near Tarnów was the site of execution of the Roma people during World War II. ${ }^{5}$ The land around the town of Miechów became the object of exploration on a wider scale, not restricted to particular focal points (again, the aim was to examine the effects of the Shoah,

3 See sites describing individual projects:

Yad Vashem: https://www.yadvashem.org/untoldstories/database/homepage.asp (access 15.11.2019); Yahad-In Unum:

http://www.yahadinunum.org/. Here one can inspect a map of identified sites: https://yahadmap.org/\#map/ (acccess 15.11.2019). The foundation is run by rev. Patrick Desbois, the author of a book that focused general attention on killing sites in the Eastern Europe (Desbois 2007). Zapomniane/Forgotten Foundation: https://www.matzevah.org/ also: https://zapomniane.org/\#map (access 15.11.2019). One should also mention the efforts to discover victims of the communist terror (from state-funded influential the Institute of National Remembrance in Poland to small scale foundations in post-soviet countries like the Soviet Past Research Laboratory in Gorgia).

4 Radecznica is a small village in Roztocze, a region in eastern Poland in Zamość County with approximately 920 inhabitants. In World War II, its small Jewish community was resettled in a ghetto in Szczebrzeszyn. A few Jews in hiding were denounced and executed. A strong underground movement was connected with the local Bernardine abbey where local partisans took often shelter. After the war, a mental hospital was opened in the buildings constructed next to the abbey. In the last decade, the church in the abbey became a mausoleum for the so called cursed soldiers of the right-wing anticommunist underground formations (the exhumed bodies found in the area by archeological missions of the Institute of National Remembrance are being moved here). The site was researched within a project by Maria Kobielska, Roma Sendyka, Aleksandra Szczepan with support of Aleksandra Janus, Jacek Małczyński, Karina Jarzyńska, Tomasz Majkowski and Katarzyna Suszkiewicz.

5 Bielcza is a village in the Brzeg powiat, in the Brzesko county, in Małopolska (Lesser Poland) Voivodship, with approximately 1,600 inhabitants. From mid-19 century, Bielcza has been frequented by Roma groups. Until the II World War a few Roma families settled and lived there. In July 1942, at least 19 Roma were murdered by German gendarmerie and Polish collaborating forces, the so called blue police. Aleksandra Szczepan and Łukasz Posłuszny and Kinga Siewior worked on that case, with the support of Roma Sendyka and Jacek Małczyński. 
but also the violence against Roma community and non-Jewish Poles) ${ }^{6}$. Sukowice (German name: Suckowitz) - the site of a mass grave of German army soldiers in the Opole region, and Dębrzyna forest near Przeworsk - the site of dispersed killings of the inhabitants at the hands of local gangs - have functioned in our research as control objects, in which uncommemorated sites were present despite the lack of cultural, ethnic, or religious difference between the community living in the area and the people buried in the pits. ${ }^{7}$ Particularly interesting cases were identified on the fringes of Nazi camps: although the areas of the - as we called it - 'peri-camps' were not included in the acts of musealisation, they were still connected with mass death or the burial of human remains. The acts of violence at the root of the sites selected for our research dated from the period of World War II and its immediate aftermath, i.e. "the great fear" (Zaremba 2012), during which the wartime anomie continued to shape social relations. Geographically, all the locations except the Kulmhof extermination camp area lie in southern Poland.

The unclear otology of the field objects necessitated, on the one hand, flexible and interdisciplinary knowledge, taking into account many specialized expert knowledge and grassroots local knowledge, and, on the other hand, the development of specific research tools. The project team comprised representatives of cultural studies, memory studies, literary studies, history, sociology, anthropology, religious studies, and political science, also experienced in education and intercultural dialogue. We also benefited from the knowledge of experts, whom we thank below; they explained to us problems related to the existence of abandoned sites in terms of central and local administrative regulations, geography, humanistic geography, non-anthropocentric history, archaeology, forensic research, ethics, Holocaust studies, research on the annihilation of the Roma, as well as digital humanities, game studies, performance studies, and visual studies. We received support from research teams and institutions working on similar issues directly in the field (RCC, Yahad-In Unum, Forgotten Foundation, Matzevah Foundation). We obtained information from local activists and residents of the towns we visited. Last but not least, our team benefited from the vital input of our collaborating visual artists.

We approached the contested locations as "theoretical objects" (Bois et al. 1998; Bal 1999), which, according to the guidelines left by the school of cultural analysis, themselves produce a "theoretical effect"; they call on the researcher to undertake a particular explanatory activity, at the same time providing her with appropriate instruments. Drawing on approaches from various research traditions, depending on the demands of particular sites selected as case studies, we combined data from field research and interviews, archive work, and artbased research. The hypothetical setting of this collective work was the "humanistic laboratory" (Kil et al. 2017), which offered a safe space for experimenting with selected 'samples', repeating research procedures, discussing the results, and, ultimately, for formulating a theoretical stance. If we were to indicate the most general framework of our activity, it would be defined by the post-anthropocentric, new materialist, and forensic turns (Forensic Architecture 2014; Dziuban 2017; Weizman 2017), as well as by environmental reorientations of historical and Holocaust studies (Małczyński et al. 2020) and new approaches to the ontology of the dead body (Anstett and Dreyfus 2017; Domańska 2017).

\section{Results: dynamic and relational microtopography of a difficult past}

Conducting research in particular locations, we adopted the practice of working in smaller teams and with various strategies. We collected all available data: from field research, interviews, extant sources (surviving documents, previous interviews, published and unpublished memoirs), local papers, loose prints, the works of vernacular researchers and artists, the activity of visiting artists and institutions, and finally from existing historical works about particular places. We strove for the greatest possible density of our field of knowledge. We were interested not only in the processes generated around the non-site of memory, but also in its interactions and interferences with its memorial environment. In Radecznica, the research was conducted in such a way as to maximize knowledge about a particular killing site, so the work model was 'fixed' and 'focal'. In Bielcza, we adopted the practice of exploring a network of other places related to the local Roma killing site, and thus the research procedure consisted in moving from location to location, capturing their

6 The Miechów area was researched by Karina Jarzyńska and Jakub Muchowski with the support of Aleksandra Szczepan and Roma Sendyka. The town is located in Małopolska (Lesser Poland) Voivodship, has approximately 12,000 inhabitants. Its development started in 12. century, when Duke Jaksa of the House of Griffins invited monks of the Order of the Holy Sepulcher. The abbey became a center of pilgrimage to the Chapel of the Tomb of Christ. Jewish settlement started here in the mid- $19^{\text {th }}$. century and by World War II approximately $40 \%$ of the inhabitants were Jewish. During the war, the Jews were resettled in a ghetto, and murdered in death camps. In the area there is also a major killing site from 1942, i.e. Chodówki forest, with 600-700 victims buried in the field.

7 Sukowice/Suckowitz - a village in Kędzierzyn-Koźle County, Opole Voivodeship, with 374 inhabitants which was a part of Germany before 1945. Today its population is mixed, Polish and German. It was researched by Maria Kobielska and Kinga Siewior with the cooperation of Roma Sendyka; Dębrzyna - a wood between two small villages: Grzęska and Świętoniowa (approximately of 800 inhabitants each), near Przeworsk (Przeworsk County, Subcarpathian Voivodeship). Site of post-war 1945-46 attacks on travelers who used the nearby train line to Rzeszów, and the USSR border. Scattered stray graves dot the wood's clearings. The case was researched by artist-ethnographer Magdalena Lubańska. Her experience, her film Not to Judge (2017, with Pawlina Carlucci Sforza) and materials gathered for this occasion became a resource for the researchers in the project on uncomemmorated sites. Jacek Małczyński interviewed Lubańska, Małczyński and Sendyka visited the site. 
dynamic relationship. In Miechów, we wanted to supplement the method of centripetal, 'vertical' probing with a 'horizontal' or 'centrifugal' analysis of a larger area: no longer a small 'town' but 'surroundings' - in order to see how a particular crime scene (a mass-killing site in Chodówki forest) functions in an extended memory plane, with which other repressed or accentuated places it enters into resonance and relations. It was important for us to take as multifaceted a view as possible, so that it would be possible to capture the relationships of a particular location with actors, objects, and memory processes. This intensive micro-memory topography revealed several common features of objects generating difficult memory.

1. The memory landscape of a particular town or village is filled with various gestures of remembrance: religious and secular, official and private. A given memorial object does not exist in a situation of exclusion, but rather in a networked relationship with other objects. It is a part of the process of proliferation, addition, supplementation of successive multivalent objects pointing to the past. It exists in relation to signs of the past which are still readable, as well as those which are already losing or have lost their meanings, and those whose meaning is undetermined or repressed. The historical and cultural contextualization of non-sites of memory reveals, as in the case of our research in the Miechów area, that they function in a dynamic network of sites and non-sites of memory.

2. A different kind of relationship is revealed when one notices that some places function as cenotaphs. A cenotaph is a symbolic object which combines and connects. It is a tomb that does not contain remains or, as in the case of tombs of an unknown soldier, it hides an unidentified body 'symbolizing' other dead people, who cannot have their own tombstones. For when a particular place is finally located and commemorated (as was the case in Radecznica thanks to the efforts of the RCC), it becomes a grave for the identified victims, but also a symbolic memorial: a substitute commemoration for other places, about which residual knowledge has survived, but, due to their small scale or difficult access/identification, no further exploratory work is undertaken in their case. Thus, non-sites of memory also remain in an internal relation to other objects of the same kind.

3. At times, there is a deep functional link between the accentuated objects and the contested ones. A special connection can be identified between nonsites of memory and nearby commemorations, which, through this 'unwanted neighborship', acquire an additional function as screen objects to the places of difficult memory in the vicinity. Thus, tracing the fate of a given location and the transformations of its significance from the time of the war to the present reveals the dynamic character of these seemingly stable objects: they function in relation to other sites and non-sites of memory. Hierarchies and tensions emerge in this arrangement, and meanings are negotiated.

4. If we perceive the plane of the local work of memory in this complex way, the conglomeration of objects of memory and non-memory will not resemble a palimpsest that would promise the possibility of typological and historical separation and ordering of meanings. What we are dealing here is rather a case of accretion (Dwyer 2004; Sendyka 2014; Pirker and Rode 2019), the "fever of adding" monuments, plaques, signs of revealing or concealing. The multiplication and mutual permeation of memory data can also be observed on the narrative plane in the form of disturbances and interferences that appear in witness testimonies regarding the location and form of commemoration or the fate of the victims.

5. The fate of non-sites of memory, if one manages to historicize it, reveals particular instability: the places of execution are transformed by the perpetrators, by the local community, and by animals living in the area. Their physical shape is influenced by natural succession. Vernacular markings (cuts, litter, boulders, mounds) and simple symbols (e.g. crosses universally used after the war for all sites of martyrdom) appear and disappear. Thus, while we are dealing with symbolization, it is worth seeing it as a symbolic process rather than a one-off act.

6. In some locations, we saw monuments being moved: brought closer to more convenient car parks or pushed back into less frequented areas. At times, then, the commemorations, set into motion, veer away from the exact place where the bodies are buried, which can still remain undefined and unprotected. The order of the protection of human remains and the order of the martyrdom discourse are therefore not always aligned. Shifts and displacements usually concern short distances: the movement of objects around the execution site may take the form of small vibrations, saccades, forcing the observer to make an effort to stabilize the field of vision.

7. Very often in our research we encountered a situation where a non-site of memory was, in a sense, distinguished by being screened off. The burial sites of many Jewish victims are now clumps of bushes. Subjecting a place to the impact of vegetation is a surprisingly ambivalent gesture: the object is obscured, but, at the same time, distinguished from its immediate anthropomorphized surroundings with a kind of 'green breach' in the landscape.

8. A variant of surrounding a problematic location with a "mnemonical security" cordon (Mälksoo 2015; Nowak et al. 2018) is littering, reported by practically all research groups working on the project. In Radecznica, people used the burial pit to dispose of cut tree branches brought from nearby homesteads, creating a compost heap. In Krępiec near Lublin, hollows left in the ground after exhumation and the 
activity of diggers in search of Jewish gold are used for illegal waste disposal. Waste desacralizes, but it also marks the area off as contaminated; hence, in a peculiar way, a given place is differentiated from the surrounding area of community activities through a paradoxical, insulting, apotropaic gesture.

9. While non-sites of memory are not graveyards, they do relate to cemetery functions and meanings; they take on features identified as topical memory of places, infused with agency. This entails the appearance of numerous proscriptions and taboos associated with a particular place (we often learned, for example, about refusal to pass through or to pick berries in a given spot). Another means of safeguarding against the power of non-sites of memory is telling stories of supernatural and potentially dangerous phenomena associated with them.

10. The dynamic character of the field of memory, which our research has identified in various locations, was above all a derivative of the unfinished process of determining who is "worthy of grief" (Butler 2009). The memory cultures which we studied have changed due to social reconfigurations within and outside the community. New subjects would appear in the field of mnemonic sensibility (e.g. Jews after 1989 ; since the beginning of the $21^{\text {st }}$ century, and especially after 2011, when a new remembrance day was established in Poland - the soldiers from the anti-communist post 1944 underground). We have also observed the diminishing importance of groups no longer included in communicative memory and no longer supported sufficiently by the local cultural memory (like the Orthodox in eastern Poland). The span of memorial attention is thus unstable, constantly reconfigured. One of the primary factors influencing the dynamic nature of the field is the unfinished process of negotiations on the question of the victims' humanity. Dehumanization is necessary in order to minimize the significance of dead bodies that have not undergone funeral rituals, and therefore remain potentially dangerous. Acknowledging the humanity of victims is an essential precondition for commencing the work of commemoration.

11. Exposing an uncommemorated site and introducing it into the field of attention can be triggered by a number of various stimuli. It may result from external intervention by an institutional or individual actor (e.g. Jonathan Webber's successful 'cultural diplomacy' with regard to memory in Brzostek; Webber 2015). Another factor may be the influence of centrally designed education, memory politics, international diplomacy or religion. The identification of a non-site of memory and its transformation into a site of memory is faster and more effective if a representative of the local community is there to testify to the humanity of the victims. The agents of humanity are the survivors of shooting executions, crime witnesses, but also younger activists.
This role is especially effective when assumed by a local authority figure: a teacher, librarian, or priest (Lubańska 2017).

12. A special communication culture functions around the contested object. Not talking about a particular place does not mean not knowing about it; there exists an alternative mode of communication about the subject. Alongside speech halting, imprecision, and vagueness, there are characteristic gestures, facial expressions, voice modulation, silences, and understated suggestions: an entire repertoire of Aesopian encryption (antonomasia, aposiopesis, metaphor, periphrasis, as well as prosody and body language) is harnessed to communicate a message about the past that escapes the attention of researchers of symbolic memory. Outdoor activity (e.g. mushroom picking, hiking, farming) is subject to minor corrections, which go unnoticed by an external observer, but remain readable to local participants of the memory culture. Drawing on the work of Polish sociologists, we define the total set of these communicatively effective yet non-symbolic measures as non-memory, a term already mentioned above (Hirszowicz and Neyman 2007; Sendyka 2016b; Nowak et al. 2018).

13. A characteristic feature of this aphasic (Stoler 2011; Nowak et al. 2018: 14) information exchange is the deliberate omission of certain words. The terms clearly avoided by our respondents included: 'Jews', 'dead bodies', 'grave'. With the need to use a particular word in an utterance comes symbolic panic, which, in turn, triggers elocutionary inventiveness, a frantic search for substitutes; often, whole cascades of euphemisms spill out as a result.

14. The decelerated, damaged articulation of the past with regard to "difficult heritage" (Macdonald 2008) contrasts with the logorrhoea of animated and loquacious accounts, which we witnessed when asking about other pasts - especially those that could be placed in the context of a personal or family history, that allowed for a heroic and gratifying, affirmative story. We listened to many wartime stories stylized to resemble a picaresque or an adventure novel. This logorrhoea can hypothetically be interpreted as compensating for the dumbness with regard to another past, or as a 'screen story', which helps create a cordon of "mnemonical security" on the communication plane.

15. A special feature of non-sites of memory is the intensity of their affective field. Due to the lack of a ready-made symbolic model for talking about such places, and the violence that had founded them in the past, these locations evoke intense emotions. Our respondents stated that when visiting them, they felt fear or anxiety; remembering such a place may cause anger or an emotional response. The accounts presently given by witnesses, who were children during the war, often seem to evoke emotions 
from the recounted moment, revealing the continued presence of a child's emotionality, not fully controlled, caused by a traumatizing event (of killing) witnessed in the past.

\section{Discussion: Non-sites of memory and their communities}

In this volume, non-sites of memory are construed as the critical obverse of sites of memory. Thus, they challenge the consequences of the modern "acceleration" of history (Nora 1989: 6). As Pierre Nora argued, acceleration has led to the loss of temporal cohesion, of a sense of the teleological nature of time, and to the weakening of institutions that govern it (e.g. the abolition of the privileged status of historians). The thus emerged "age of commemoration" (Nora 1984-1992) is founded on a feeling of desperation: it is characterized by the society's obsession "with the archive that marks our age, attempting at once the complete conservation of the present as well as the total preservation of the past" (Nora 1989: 13). Contested places allow us to ask: does this "dangerous supplement" to official memories, lodged in, as Rothberg identified it, "gaps", "omissions" or "surprising absences" of Nora's project, derive from the modern experience just like lieux de mémore (Rothberg 2010: 5-7)? Or, on the contrary, do non-sites of memory testify to a denial of the very paradigm of modern time, to a return to the time before modernity? In other words, do non-sites of memory belong to the practices of the modern society or pre-modern millieux de mémoire? (Bogumił and Głowacka-Grajper 2019)

Non-sites of memory indeed demonstrate the complex, non-binary nature of remembering. Consequently, they also oppose Nora's antinomic conceptualization at the meta-structural level. Since the concept of millieux de mémoire is merely hypothetical, nothing stands in the way of treating the phenomena observed around non-sites of memory as residual traces of how memory used to function prior to being sustained by mediatized records. Thus, these phenomena can also be studied in terms of the archaeology of social forms of relating to the past. Especially the acknowledgement of the role of extra-symbolic interaction may bring new data concerning the complexity of forms of remembering, which combine explicitly articulated and hidden elements.

Another potentially fruitful research path opens thanks to the development of post-anthropocentric approaches. Perhaps the question about the type of community implied by a particular contested place should go beyond traditional social research. When there was talk near Miechów about cereal grains that had gone black year after year, marking out in the field the burial place of victims of German executions, this suggested a non-human guardian of human history, an environmental 'marker/memorial, trans-species solidarity in giving a testimony of violence.
In our research, the communities around non-sites of memory are therefore analyzed beyond the opposition of modernity and post-modernity (Augé 1992) or modernity and pre-modernity (Nora 1984-1992). We emphasize complex strategies of remembering and ambiguous motivations and actions associated with it. As our findings suggest, more fitting are relational, dynamic, non-antinomic models, such as the concept of social implication, which, following Rothberg and Lehrer (Lehrer 2018; Rothberg 2019), we propose to apply (Sendyka 2018).

\section{Conclusions: non-sites of memory as a diagnostic tool for memory studies}

In the broadest sense, non-sites of memory, investigated within the range of their influence, but also as theoretical and critical objects, can become diagnostic objects with regard to strategies of relating to the past, especially in cases where violence has permanently affected social relations and the possibility of their articulation. We propose to understand non-sites of memory as objects which allow to diagnose problems through coordinating and effecting reconciliation of cultural memory, whether in the official or vernacular dimension. They are certainly not the only or exclusive phenomena offering insight into that which has been pushed out of the symbolic imaginarium, and is not manifested in the area of cultural memory, while remaining mnemonically active. Contemporary memory studies have developed primarily tools for researching cultural memory founded on the act of symbolization. In our project, we inquire about the possibilities and needs of expanding these research techniques in a way that would enable capturing memory when its expression is not based on a code that allows us to order the signifying and the signified, but rather on acts which are not yet or not fully encoded semiotically.

Below we present articles whose extended versions will be published in Polish in two edited volumes: Nie-miejsca pamięci (1). Nekrotopografie [Non-sites of memory (1) Necrotopographies (Sendyka, Kobielska, Muchowski, Szczepan 2020) and Nie-miejsca pamięci (2). Nekrotopologie [Non-sites of memory (2) Necrotopologies] (Sendyka, Janus, Jarzyńska, Siewior 2020). The participants of the "Uncommemorated Genocide Sites" project propose interpretations of social, communicational, and cultural phenomena testifying to the present state of memory culture around uncommemorated sites of violence. Interpretations of mnemonic events generated by non-sites of memory constitute both pioneering attempts at understanding and explaining the collected data, and theoretical proposals for a terminology and research tools applicable to complex objects testifying to the operations of repressed memory. Potentially, therefore, the studies presented below may be used not only to explore other post-violence sites, but also, more broadly, objects 
pushed out of the field of official collective and communicative memory.

The presentation opens with Aleksandra Szczepan and Kinga Siewior's discussion of the peculiar cartography of non-sites of memory. They can be found on unofficial maps drawn to support the narrative during depositions by witnesses to the crime (bystanders, interviewed after the war in relation to the war-time executions). On this basis, the authors develop a topological theory of non-sites of memory. Maria Kobielska and Aleksandra Szczepan propose their reading of the category of the witnesses, which has recently been debated with increasing intensity (Morina and Krijn 2018). They arranged a lexicon of productive sub-notions like "crown/summoned/volunteer/outcast" witness or witnessing "object/gesture/performance", The authors develop a dynamic interpretation of the witness in epistemological rather than ontological terms: as a variable and transitive disposition of "testimoniality". Jakub Muchowski comments on historians' practices of coming to terms with repressed crime scenes. While official historical discourses follow limited information, scattered in the archives, local historians have developed at least several strategies of working with this difficult topographical heritage. Aleksandra Janus investigates the manner and conditions of the emergence of remembering communities in non-sites of memory, the role played here by human and non-human agents. She also presents an interesting example of conciliatory forms of commemoration. Maria Kobielska proposes a close reading of the unveiling of a memorial to murdered Jews in one of the locations that have been the object of our research. She precisely identifies the difficulties with putting the past into safe language formulations and the defense or escape strategies that lead to avoidance of contested issues, to non-antagonizing, justifying, to whitewashing the difficult past. Katarzyna Grzybowska investigates a surprising practice associated with past attempts at mapping nonsites of memory, namely the 1965 action of involving young scouts in the search for uncommemorated sites. In this way, she reveals former strategies of responding to the alert of post-violence sites. Roma Sendyka and Aleksandra Janus discuss artists' present-day responses to the imploration of places difficult to grasp. Bystander art, always belated, is analyzed as a form of art-based research, of deepened exploration of non-sites of memory. Katarzyna Suszkiewicz and Tomasz Majkowski present a report on the experiment of building active memory and supportive attitudes among young people. A game jam organized in one of the towns has brought very interesting educational results. The volume is concluded with a transcript of conversations and discussions from the conference Sites of Violence and Their Communities: Critical Memory Studies in the Post-Human Era, held in Kraków on 23-25 September 2019 (organizers: Research Center for Memory Cultures, Faculty of Polish Studies, Jagiellonian University; Polish Studies Program, Cambridge University; Yahad-In Unum). The texts published below were first presented as papers at that event.

Translated by Zofia Ziemann

\section{Acknowledgements}

The articles presented in this issue were prepared within the scope of the project: "Uncommemorated Genocide Sites and Their Impact on Collective Memory, Cultural Identity, Ethical Attitudes and Intercultural Relations in Contemporary Poland" (Polish Ministry of Science and Higher Education, the National Programme for the Development of Humanities, 2016-2020, registration no 2aH 150121 83) developed in the Research Center for Memory Cultures, Faculty of Polish Studies, Jagiellonian University. Principal investigator: Roma Sendyka, team members: Katarzyna Grzybowska, Aleksandra Janus, Karina Jarzyńska, Maria Kobielska, Jacek Małczyński, Jakub Muchowski, Łukasz Posłuszny, Kinga Siewior, Mikołaj Smykowski, Katarzyna Suszkiewicz, Aleksandra Szczepan.

The team members are very thankful to all who made our research possible. The indispensable institutional frame was offered by the National Programme for the Development of Humanities, and by the Faculty of Polish Studies, Jagiellonian University. We are grateful for the support of cooperating institutions: Yahad-In Unum, The Rabbinical Commission for Jewish Cemeteries in Poland, The Polish Studies Programme (University of Cambridge), Fundacja Zapomniane/'Forgotten' Foundation, the Matzevah Foundation, and all the organizations, associations and foundations that made the archival research possible. We are indebted to experts that supported our reasoning: Tim Cole, Patrick Desbois, Ewa Domańska, Jean-Marc Dreyfus, Zuzanna Dziuban, Jason Francisco, Dorota Głowacka, Sławomir Kapralski, Marta Kurkowska-Budzan, Joanna Michlic, Robert van der Laarse, Bryce Lease, Erica Lehrer, Jacek Leociak, Magdalena Lubańska, Tomasz Majkowski, Christina Morina, Susan Schuppli, Caroline Sturdy Colls, Joanna Talewicz-Kwiatkowska, Krijn Thijs, Barbara Törnquist-Plewa, Piotr Trojański, Joanna Wawrzyniak, Jonathan Webber, Tomasz Żukowski, Józef Żychowski. We would like to express our deepest thanks to memory activists, interviewees and witnesses who shared their knowledge with us. We were also generously supported by the following artists: Karolina Grzywnowicz, Angela Henderson, Małgorzata Mirga-Tas, Solomon Nagler, Susan Schuppli, Anna Zagrodzka, and Artur Żmijewski.

We would like to express our gratitude to the participants of the workshop From Violence of War to the Violence of Transformation. Memory Cultures of Contemporary Poland that concluded the conference Memory Studies in Poland, and on Poland (Department of Sociology, University of Warsaw; Faculty of Polish Studies, Jagiellonian University, Krakow 2018) and to the participants of the final, international conference of our project: Sites of Violence and Their Communities: Critical Memory Studies in the Post-Human Era (Krakow 2019).

We are grateful to the reviewers, especially Ewa Domańska, Arkadiusz Żychliński, Zuzanna Dziuban. We would like also to thank the editors and translators of this work for helping to bring this project to fruition. 


\section{References}

Anderson P (2004) Union Sucrée. London Review of Books. 23 September. https://www.lrb.co.uk/the-paper/v26/n18/perry-anderson/ union-sucree

Anstett É, Dreyfus J-M (2017) Human Remains and Identification. Oxford University Press, Oxford, 264 pp. https://doi. org/10.7765/9781526125019

Assmann A (1999) Erinnerungsräume: Formen und Wandlungen des kulturellen Gedächtnisses. C.H. Beck, Munich, 424 pp.

Augé M (1992) Non-lieux. Introduction à une anthropologie de la surmodernité. Le Seuil, Paris, 155 pp.

Bal M (1999) Narrative inside out: Louise Bourgeois' Spider as Theoretical Object. Oxford Art Journal 2: 101-126. https://doi.org/10.1093/ oxartj/22.2.101

Bogumił Z, Głowacka-Grajper M (2019) Milieux de mémoire in Late Modernity. Local Communities, Religion and Historical Politics. Peter Lang, Bern, 298 pp. https://doi.org/10.3726/b15596

Bois Y-A, Hollier D, Krauss R, Damisch H (1998) A Conversation with Hubert Damisch. October 8: 3-17. https://doi.org/10.2307/779179

Butler J (2009) Frames of War: When Is Life Grievable? Verso, London, $193 \mathrm{pp}$.

Cole T (2016) Holocaust Landscapes. Bloomsbury, London, 272 pp.

Cole T, Knowles AK, Giordano A [Eds] (2014) Geographies of the Holocaust. Indiana University Press, Bloomington, 260 pp.

David L (2017) Against Standardization of Memory. Human Rights Quarterly 39(2): 296-318. https://doi.org/10.1353/hrq.2017.0019

Desbois P (2007) Porteur de mémoires: sur les traces de la Shoah par balles. Michel Lafon, Paris, 325 pp.

Didi-Huberman G (1998) Phasmes. Essais sur l'apparition. Minuit, Paris, $256 \mathrm{pp}$.

Domańska E (2017) Nekros. Wprowadzenie do ontologii martwego ciała. PWN, Warszawa, 370 pp.

Dwyer OJ (2004) Symbolic Accretion and Commemoration. Social \& Cultural Geography 3: 419-435. https://doi. org/10.1080/1464936042000252804

Dziuban Z [Ed.] (2017) Mapping the "Forensic Turn": Engagements with Materialities of Mass Death in Holocaust Studies and Beyond. New Academic Press, Wien, 368 pp.

Engelking B, Grabowski J [Eds] (2018) Dalej jest noc. Losy Żydów w wybranych powiatach okupowanej Polski. Centrum Badań nad Zagładą Żydów, Warszawa, vol. 1; 868 pp; vol. 2, 832 pp.

Eisenhuth S, Sabrow M [Eds] (2017) Schattenorte: Stadtimages und Vergangenheitslast. Wallstein, Göttingen, $184 \mathrm{pp}$.

Erll A (2011a) Memory in culture. Transl. Young SB. Palgrave Macmillan, New York, 218 pp. https://doi.org/10.1057/9780230321670

Erll A (2011b) Travelling Memory. Parallax 4: 4-18. https://doi.org/10. 1080/13534645.2011.605570

Forensic Architecture [Eds] (2014) Forensis: The Architecture of Public Truth. Sternberg Press, Berlin, 763 pp.

François E, Schulze H [Eds] (2001) Deutsche Erinnerungsorte. I-III. C.H. Beck, München, 2250 pp.

Głowacka D (2016) Współ-pamięć, pamięć 'negatywna' i dylematy przekładu w 'wycinkach' z Shoah Claude’a Lanzmanna. Teksty Drugie 6: 297-311. https://doi.org/10.18318/td.2016.6.17

Hayden D (1997) The Power of Place: Urban Landscapes as Public History. MIT Press, Boston, 316 pp.
Hirszowicz M, Neyman E (2001) Społeczne ramy niepamięci. Kultura i Społeczeństwo 3-4: 23-48.

Hirszowicz M, Neyman E (2007) The Social Framing of Non-Memory. International Journal of Sociology 1: 74-88. https://doi.org/10.2753/ IJS0020-7659370105

Huyssen A (1997) The Voids of Berlin. Critical Inquiry 1: 57-81. https:// doi.org/10.1086/448867

International Holocaust Remembrance Alliance (2015) Killing Sites Research and Remembrance. Metropol Verlag, Berlin, 324 pp.

Kaplan BA (2010) Landscapes of Holocaust Postmemory. Routledge, New York, 272 pp. https://doi.org/10.4324/9780203842270

Kil A, Małczyński J, Wolska D (2017) Ku laboratorium humanistycznemu. Teksty Drugie 1: 274-285. https://doi.org/10.18318/ td. 2017.1 .23

Kwiatkowski PT (2009) Społeczne tworzenie zbiorowej niepamięci. In: Nijakowski LM (Ed.) Etniczność, pamięć, asymilacja. Wokół problemów zachowania tożsamości mniejszości narodowych i etnicznych w Polsce. Wydawnictwo Sejmowe, Warszawa, 90-128.

Laarse van der R, Mazzucchelli F, Reijnen C [Eds] (2014) Traces of Terror, Signs of Trauma: Practices of (re)presentation of Collective Memories in Space in Contemporary Europe. Versus: Quaderni di Studi Semiotici 119, 180 pp.

LaCapra D (1997), Lanzman's “Shoah": Here There Is No Why. Critical Inquiry 2: 231-269. https://doi.org/10.1086/448828

Lanzmann C (1990) Les Non-Lieux de la Mémoire. In: Deguy M (Ed.) Au sujet de Shoah: Le Film de Claude Lanzmann. Éditions Berlin, Paris, 280-292.

Lanzmann C (2007) Site and Speech. Transl. Liebman S. In: Liebman S (Ed.) Claude Lanzmann's Shoah. Key Essays. Oxford University Press, Oxford, 37-49.

Lanzmann C, Gantheret F (1986) L'Entretien de Claude Lanzmann, Les non-lieux de mémoire. Nouvelle Revue de Psychanalyse 33: 293-305.

Lehrer ET (2018) From 'Heritage Communities' to 'Communities of Implication’. Traces Journal. http://www.traces.polimi.it/index. html@p=3595.html

Liebeskind D (2003) Trauma. In: Hornstein S, Jacobowitz F (Eds) Image and Remembrance: Representation and the Holocaust. Indiana University Press, Bloomington, 43-58.

Lubańska M (2017) Postmemory of Killings in the Woods at Dębrzyna (1945-46): A Postsecular Anthropological Perspective. Ethnologia Polona 38: 15-45.

Macdonald S (2008) Difficult Heritage: Negotiating the Nazi Past in Nuremberg and Beyond. Routledge, London, $228 \mathrm{pp}$.

Małczyński J (2018) Krajobrazy Zagłady. Perspektywa historii środowiskowej. IBL PAN, Warszawa, 246 pp.

Małczyński J, Domańska E, Smykowski M, Kłos A (2020) The Environmental History of the Holocaust. Journal of Genocide Research 2: 183-196. https://doi.org/10.1080/14623528.2020.1715533

Mälksoo M (2015) "Memory Must Be Defended": Beyond the Politics of Mnemonical Security. Security Dialoguge 3: 221-237. https:// doi.org/10.1177/0967010614552549

Morina C, Thijs K (2018) Probing the Limits of Categorization: The Bystander in Holocaust History. Berghahn Books, New York, 382 pp. https://doi.org/10.2307/j.ctvw04hm8

Nora P (1984-1992) Les Lieux de mémoire, vol. I-III. Gallimard, Paris, $4800 \mathrm{pp}$. 
Nora P (1989) Between Memory and History: Les Lieux de Memoire. Transl. Roudebush M. Representation 26: 7-24. https://doi org/10.2307/2928520

Nowak J, Kapralski S, Niedźwiedzki D (2018) On the Banality of Forgetting: Tracing the Memory of Jewish Culture in Poland. Peter Lang, Bern, 276 pp. https://doi.org/10.3726/b14412

Otto L (2009) Postcommunist Museums: Terrorspaces and Traumascapes. In: Kjeldbæk E (Ed.) The Power of the Object: Museums and World War II. MuseumsEtc, Edinburgh, 424 pp.

Pirker R, Rode P, Lichtenwagner M (2019) From palimpsest to memoiré: Exploring urban memorial landscapes of political violence. Political Geography 74: 102057. https://doi.org/10.1016/j.polgeo.2019.102057

Pollack M (2014) Kontaminierte Landschaften: Unruhe bewahren. Residenz Verlag, Salzburg, 120 pp.

Rapson J (2015) Topographies of Suffering: Buchenwald, Babi Yar, Lidice. Berghan Books, New York, 242 pp. https://doi.org/10.2307/j.ctt9qcxfx

Rothberg M (2010) Introduction: Between Memory and Memory: From Lieux de mémoire to Noeuds de mémoire. Yale French Studies 118/119: 3-12.

Rothberg M (2019) The Implicated Subject: Beyond Victims and Perpetrators. Stanford University Press, Stanford, 288 pp. https://doi. org/10.1515/9781503609600

Saryusz-Wolska M (2011) Spotkania czasu z miejscem. Studia o pamięci i miastach. Wydawnictwo Uniwersytetu Warszawskiego, Warszawa, 448 pp.

Schmidt P (2004) Zwischen Medien und Topoi. Die Lieux de mémoire und die Medialität des kulturellen Gedächtnisses. In: Erll A, Nünning A (Eds) Medien des kollektiven Gedächtnisses. Konstruktivität - Historizität - Kulturspezifität. Walter de Gruyter: Berlin, New York, 25-44. https://doi.org/10.1515/9783110201789.2.25

Sendyka R (2014) Prism. Understanding Non-Sites of Memory. Transl. Croft J. In: Boyer JW, Molden B (Eds) EUtROPEs: the paradox of European empire. University of Chicago Press, Chicago, 183-201.
Sendyka R (2016a) Sites That Haunt: Affects and Non-sites of Memory. East European Politics and Societies: and Cultures 4: 687-702. https://doi.org/10.1177/0888325416658950

Sendyka R (2016b) Niepamięć albo o sytuowaniu wiedzy o formach pamiętania. Teksty Drugie 6: 250-267. https://oi.org/10.18318/ td.2016.6.14

Sendyka R (2018) Caduca, or es(cheat)ed heritage. Traces Journal. http:// www.traces.polimi.it/2018/07/26/caduca-or-escheated-heritage/

Snyder T (2010) Bloodlands: Europe between Hitler and Stalin. Basic Books, New York, 534 pp.

Stoler LA (2011) Colonial Aphasia: Race and Disabled Histories in France. Public Culture 1: 121-156. https://doi. org/10.1215/08992363-2010-018

Szczepan A (2014) Krajobrazy postpamięci. Teksty Drugie 1: 103-126. Tai H-TH (2001) Remembered Realms: Pierre Nora and French National Memory. The American Historical Review 3: 906-922. https:// doi.org/10.2307/2692331

Tumarkin M (2015) Traumascapes: The Power and Fate of Places Transformed by Tragedy. Melbourne University, Melbourne 2005, 279 pp.

Violi P (2012) Trauma Site Museums and Politics of Memory. Tuol Sleng, Villa Grimaldi and the Bologna Ustica Museum. Theory, Culture \& Society 1: 36-75. https://doi. org/10.1177/0263276411423035

Webber J (2015) A Jew, a Cemetery, and a Polish Village: A Tale of the Restoration of Memory. In: Lehrer ET, Meng M (Eds) Jewish Space in Contemporary Poland. Indiana University Press, Bloomington, 238-263.

Weizman E (2017) Forensic Architecture: Violence at the Threshold of Detectability. Zone books, New York, 376 pp. https://doi. org/10.2307/j.ctv14gphth

Zaremba M (2012) Wielka trwoga. Polska 1944-1947. Ludowa reakcja na kryzys. Znak, Instytut Studiów Politycznych PAN, Kraków, $700 \mathrm{pp}$. 